\title{
MEASURES TO SUPPORT THE DEVELOPMENT OF ORGANIC FARMING IN THE EU AND SERBIA ${ }^{1}$
}

\author{
Svetlana Roljević Nikolić2 ${ }^{2}$ Predrag Vuković3 ${ }^{3}$ Biljana Grujićc
}

\begin{abstract}
Aim of this paper work is analyzing the situation in the sector of organic agriculture, as well as system of support that this production provides in the European Union and Serbia. Organic farming shows a dynamic process of growth and development, especially in economically developed countries. In the past ten years, the area under organic production in the EU increased by $70 \%$, the number of certified producers increased by $60 \%$, while the total market value doubled. On the other hand, the growth and development of organic agriculture in Serbia is very slow. Currently, the area under organic production accounted for only $0.4 \%$ of total utilized agricultural area, while in this mode of food production certified $0.3 \%$ of the total number of farms.

Intensive growth of organic farming in the EU provides a stable support both in terms of rate and financial resources, while in Serbia has been changed not only amount of support from year to year but also types of support. On this basis, it can be concluded that a stable government support is crucial for boosting growth and improving the sector of organic agriculture.
\end{abstract}

Key words: organic agriculture, agricultural policy, support measures

JEL: Q14, Q15, Q18

1 Paper work is part of the project III 46006 - "Sustainable agriculture and rural development in function of Republic of Serbia strategic goals achievement within the Danube region", and project 179028 „Rural work market and rural economics of Serbia - diversification of income and decrease of rural poverty " financed by the Ministry of Education and Scence Republic of Serbia, member of researching team, period 2011-2014.

2 Svetlana Roljevic Nikolic Ph.D. Research associate, Institute of Agriculture Economics, Belgrade, Volgina Street no. 15, 11060 Belgrade, Serbia, E-mail: svetlana_r@iep.bg.ac.rs , Phone: +381 116972858.

3 Predrag Vukovic Ph.D. Research assistant, Institute of Agricultural Economics, Belgrade, Volgina Street no. 15, 11060 Belgrade, Serbia, E-mail: predrag_v@_iep.bg.ac.rs , Phone: +381 116972858 .

4 Biljana Grujić M.Sc. Research assistant, Institute of Agricultural Economics, Belgrade, Volgina Street no. 15, 11060 Belgrade, Serbia, E-mail: biljana_g@iep.bg.ac.rs

EP 2017 (64) 1 (323-337) 


\section{Introduction}

Further development of industrialized agriculture are increasingly be bringing into question for the reason that the global food chain and natural resources residues were burdens with persistent pesticides, nitrates, and all the worse organoleptic and nutritional properties of the thus obtained food. Therefore, in recent decades, it has been developed concepts of agricultural production which are based on natural balance of the system soil-plant-animal-man. Such forms of production falls and organic agriculture. Organic farming represents a comprehensive system of farm management and food production that protects environment, preserves biodiversity and natural resources. The sustainability of organic production is reflected in the rational use of natural resources, without exhausting, but rather through maintaining and increasing their diversity, leaving no negative impacts on the environment. This system is controlled and subject to inspection, which is why it has the trust of consumers in terms of quality and food safety (Roljević, 2014).

Researches around the world have shown that the production which is based on the principles of organic agriculture gives lower crop yields than conventional, but lower yields could be compensate with numerous benefits that organic farming bring. For agriculture these are: increased soil fertility, stable production and high quality food; for the environment are: reduced pollution and conservation of agro-ecosystems; for the economy: income security and strengthening local communities; and the promotion of public health is the starting point and ultimate goal of organic production.

Today, organic agriculture is practiced in 172 countries around the world, on around 40.3 million hectares (1\% of global agricultural land), on which there are registered 1.8 million farms (FiBL-IFOAM, 2016).

For the EU, organic farming is practiced by 10.3 million ha, which represents $23.5 \%$ of global land area under organic production. The number of registered organic producers in 2014 at the EU amounted to 257,525 , which is $2.4 \%$ compared to the total number of farms (Eurostat, 2016).

Compared to developed countries, organic agriculture in Serbia is of recent date, so the size of the soil area under this type of food production is not large. According to data from 2015 (Direction for National referent laboratories, 2015), there are 15.298 ha under organic production in Serbia, or $0.4 \%$ of total agricultural land, which indicates that the current scope of this practice is much smaller than the real potential.

In the European Union has been developed support policy for organic agriculture on several levels as well as environmentally friendly production system during the last two decades. The first system of support measures to organic farming was established in Denmark in 1987, and this case were quickly followed by other countries. Today there are numerous of different measures that are financed from different sources, which are aimed at stimulating the expansion of organic farming in the EU. 


\section{Organic farming in the European Union}

Organic agriculture in the world is evolving at a rapid pace in response to increasingly marked deterioration of health of the environment, the decreasing availability of natural resources and the deterioration of the quality of the food. Awareness about importance of organic agriculture is present especially in economically powerful countries where this type of food production and encourages and supported. At the level of the European Union in 2005 the area under organic production (certified land and land under conversion) accounted for 6.5 million ha, while in 2015 increased to 11 million hectares, which is 70\% more compared to 2005 (Eurostat, 2017).

The largest growth in this period was in Bulgaria, where the area under organic production increased 25 times. A significant increase in the area under organic production in the reported period was recorded in Poland (3,6 times), Lithuania (3,3 times) and Belgium (3 times).

Graphic 1. Area under organic production in EU Member States

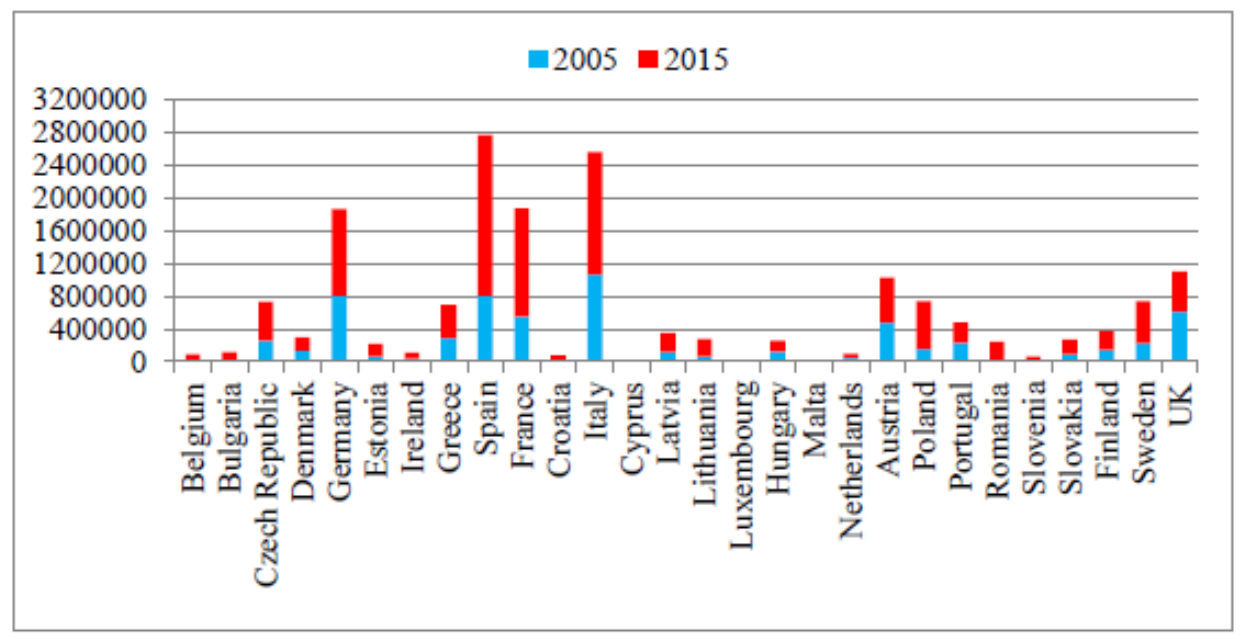

Source: Eurostat, 2017.

Areas under organic production differ significantly between Member States. Generally, the larger countries have more surface area under organic production.

According to Eurostat data most of the area is located in Spain (1,968,570 ha), Italy $(1,492,579$ ha), France $(1,322,911 \mathrm{ha})$ and Germany $(1,060,291 \mathrm{ha})$, which disposes of $50 \%$ of the total organic surface of the European Union (graph 1).

However, if we consider the share of organic area in total the usable agricultural area (UAA) gives a clearer picture of the importance of the organic sector in each of the member states and their ranking is quite different. According to data from Eurostat (date of access to data 14.02.2017) the share of organic area in total used agricultural area is the largest in Austria (20.3\%), followed by Sweden (17.1\%) and Estonia (15.7\%). The 
share of organic area in the UAA over $10 \%$ is found in the Czech Republic (13.7\%), Italy $(11.8 \%)$ and Latvia (12.3\%). On the other hand, a very small proportion of the organic UAA are found in Malta $(0.3 \%)$, Romania (1.8\%) and Hungary $(2.4 \%)$. The share of organic area (certified land and land under conversion) in the usable agricultural area at the level of the EU is $5.9 \%$.

As for the categories of used soil the largest share of the organic surfaces is held by perennial grasslands (46\%), followed by arable land (43\%), and the lowest share is held by areas under perennial crops (11\%). A similar situation is also observed at the global level.

In order to obtain a clearer picture of interest in organic agriculture in some country, the growth dynamics of the area under organic production should be analyzed together with changes in the number of producers in this sector. Eurostat data (graph 2) show that the number of producers on the EU level in 2015 increased by 1.6 times compared to 2005. The number of producers of organic food in 2015 at the level of the EU amounted to 271,547 , which is $2.5 \%$ of the total number of households (10.8 million).

Graphic 2. The number of organic producers in the EU during the period 2005-2015.

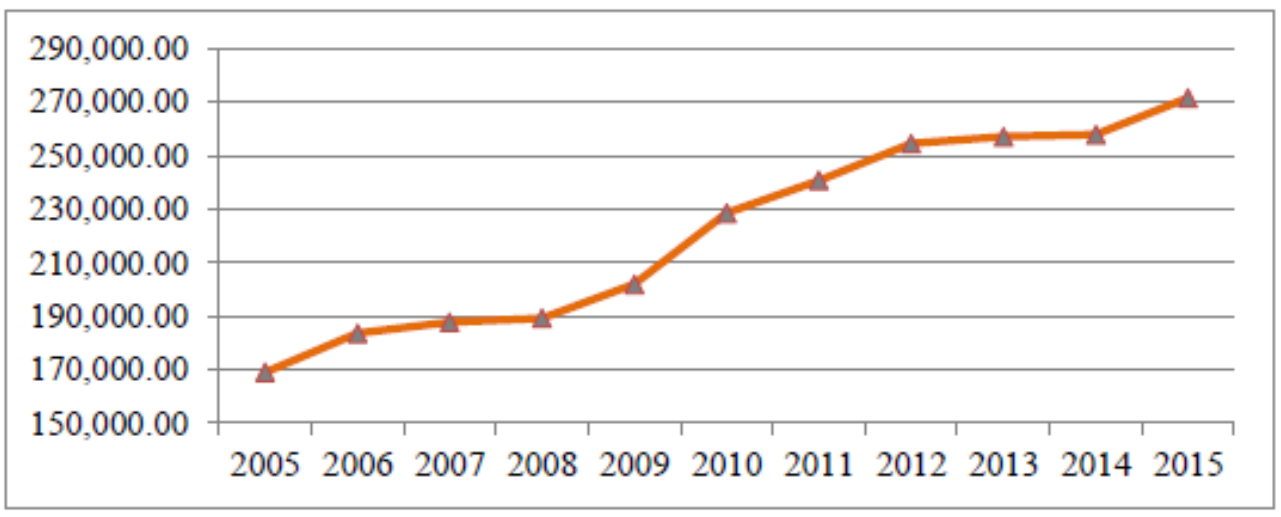

Source: Eurostat, accessed 13.02.2017.

Most registered organic producers are located in Italy $(52,609)$, Spain $(34,673)$, France $(28,884)$ and Germany $(25,078)$ and account for $52 \%$ of the total number of organic producers in the EU.

Increases in area under organic production have been accompanied by dynamic growth of an organic products market. The total value of the organic market in the European Union in 2005 was 11.1 billion euros, while in 2014 it doubled, and according to Willer et al. (2015) amounted to 24 billion euros. At the same time, the retail value of organic products in the EU is the second largest single market for organic products in the world, after the US (27.1 billion $€)$.

The consumption of organic products per capita in the EU during the period 2005-2014 increased by $110 \%$, or more precisely from $€ 22.4$ to $€ 47.4$. The consumption of organic food per capita in Europe in general, particularly at the global level, is considerably 
lower (table 1). Sima and Gheorghe (2015) suggest that it is precisely the change in consumer habits, determine the a transition to a green economy.

Table 1. Organic market and production trends in Europe by country group, 2014

\begin{tabular}{|l|l|l|l|l|l|}
\hline $\begin{array}{l}\text { Country } \\
\text { group }\end{array}$ & $\begin{array}{l}\text { Retail sales } \\
\text { (billion EUR) }\end{array}$ & $\begin{array}{l}\text { Per capita } \\
\text { consumption } \\
\text { (EUR) }\end{array}$ & Producers & $\begin{array}{l}\text { Land area } \\
\text { (million ha) }\end{array}$ & $\begin{array}{l}\text { Total land } \\
\text { share (\%) }\end{array}$ \\
\hline EU 28 & 24,0 & 47,4 & 257.525 & 10,3 & 5,7 \\
\hline Evropa & 26,2 & 35,5 & 339.824 & 11,6 & 2,4 \\
\hline Global & 62,6 & 8,3 & 2.260 .361 & 43,7 & 1,0 \\
\hline
\end{tabular}

Source. Willer et al., 2015

Dynamic growth is a result of continuous improvement and the introduction of innovations in the system of organic agriculture in order to respond to the high expectations and demands of consumers for quality food, support for the health of the environment, animal welfare and rural development. However, despite the rapid growth of the sector of organic farming, there still exists an imbalance between the volume of production and the growing demand for organic food.

\section{The support policy for organic agriculture in the European Union}

Sector of organic farming in European Union is regulated by the Council Regulation (EC) No 834/2007 defining the official EU aims, objectives and principles of organic farming and production. Council Regulation follow two Commission regulations, Commission Regulation (EC) No. 889/2008 with the detailed rules for production, labeling and control, including the first amendment to the rules on production of organic yeast and Commission Regulation (EC) No. 1235/2008 detailed rules regarding the import of organic products from third countries.

During the past two decades, policy support for organic agriculture in the European Union has been developed on several levels, but it was only through introduction of agri-environment programs and measures under framework of the Common Agricultural Policy (CAP) in 1992 created a unique base for supporting the expansion of organic farming in the EU (Lampkin et al., 1999, Padel et al., 2007). CAP is based on the concept of multifunctionality, and strives to meet the demands of consumers in terms of food availability, its price, quality and safety, then to protect the health of the environment and allow farmers to live from their activities.

The Concept of Common Agricultural Policy is based on two pillars:

I. Direct subsidies to farmers and support for the market of agricultural products include direct financial assistance to farmers in order to provide a stable income. To be eligible for subsidies, farmers must now respect the principle of cross-compliance, which is based on two sets of rules. The first relates to the regulations in the production concerning the protection of the environment, human health, plant and animal welfare, 
while the second group relates to good agricultural practice with the aim of preserving the land in good condition.

II. Rural development. Rural development policy is implemented through three elements: (1) improving the competitiveness of the agriculture and forestry, (2) improving environmental protection and rural areas, and (3) improving life in rural areas and diversification of the rural economy. All rural development programs must include measures for the protection and improvement of natural resources and the environment in rural areas in which organic farming is fully fit.

The reform of the CAP for new strategic framework 2014-2020 is aimed at a more equitable distribution of budget funds between Member States, the most significant changes in the policy relating to the introduction of so-called (EC, 2013). "Green payments", which will in the long term, make possible sustainable food production, sustainable management of natural resources in terms of climate change and balanced territorial development (Westhoek et al., 2014). In short, the agriculture of the European Union should achieve a higher level of safe and quality food, while preserving the natural resources on which it directly depends.

Agri-environmental programs of the CAP encourage and stimulate farmers to be more environmentally conscious, and use financial assistance to direct farmers to adapt their conventional agricultural practice to methods of sustainable use and management of natural resources, in particular through the reduction of the number and amount of synthetic agents that are used in the production process and reducing the number of animals per hectare of arable land. Since 2015, all EU Member States will have to focus $30 \%$ of the funds meant for direct payments to farmers on financing sustainable agricultural practices, and on making the Common Agricultural Policy "greener" (EC, 2013). Greening can be implemented through three basic measures:

1. Maintaining perennial grasslands;

2. Diversification of crops, where a farmer must cultivate at least two crops at a time when arable land on the holding exceeds 10 ha, and at least three crops when arable land exceeds 30 hectares;

3. Maintaining protected/focus areas at least 5\% of arable land on farms larger than 15 hectares (excluding permanent grassland) - i.e. maintenance of fallows, preserving the characteristics of the landscape, buffer zones, forested areas, nitrogen fixing and intercrop (EC, 2013).

Besides, at least 30\% of the budget European Agricultural Fund for Rural Development (EAFRD) should focus on support for environmental measures and measures to combat climate change, including organic agriculture.

Expected budget support to environmental protection and the fight against climate change in the context of the second axis is approximately 29.7 billion euros (Table 2), which is not only a contribution to the environment, but also helps the development of 
organic agriculture sectors in which the EU has the potential to become a leader in the global market.

Table 2. Key EU budget allocations for transitioning towards environmental and climate friendly practices and organic farming under the CAP 2014-2020 (Indicative figures)

\begin{tabular}{|c|c|c|c|}
\hline & $\begin{array}{l}\text { Billion } \\
\text { Euro }\end{array}$ & $\begin{array}{l}\text { \% of total } \\
\text { EAFRD }\end{array}$ & $\begin{array}{l}\text { \% of total EU } \\
\text { budget for } \\
\text { agriculture }\end{array}$ \\
\hline Pillar 1 - Market related expenditure and direct payments & 312.7 & & 76 \\
\hline Total national ceilings for direct payments & 297.6 & & 72.3 \\
\hline Greening component (maximum 30\% of direct payments) & 89.3 & & 21.7 \\
\hline Pillar 2-Rural development & 99 & & 24 \\
\hline $\begin{array}{l}\text { Contribution to environment \& climate issues - including } \\
\text { organic farming (minimum } 30 \% \text { of EAFRD) }\end{array}$ & 29.7 & 30 & 7.2 \\
\hline \multicolumn{4}{|l|}{ Organic farming support (conversion and maintenance payments) } \\
\hline$-\quad$ EAFRD organic farming support (Measure 11) & 6.3 & 6.4 & 1.5 \\
\hline $\begin{array}{l}\text { - Total public expenditure (EU and Member States) for } \\
\text { organic farming support (Measure 11) }\end{array}$ & 9.9 & & \\
\hline $\begin{array}{l}\text { Total environmental and climate change spending for } \\
\text { agriculture (Pillar } 1 \text { and Pillar 2) }\end{array}$ & 119 & & 28.9 \\
\hline Total EU budget for agriculture (Pillar 1 + Pillar 2) & 411.7 & & 100 \\
\hline
\end{tabular}

Source: Stolze et al., 2016

When it comes to organic farming, the majority of Member States apply the system of direct payments to cover additional costs and reduce losses resulting from implementation of a system of organic management. The support system is usually implemented within Axis 2 (improving environmental protection and rural areas), or under Article 68 of Regulation EC 73/2009 (Specific support to farmers). A large number of Member States and regions also apply support for organic agriculture in context of Axis 1 (improving competitiveness of the agricultural and forestry sector) and that in most cases no or only partially exsist special provisions for organic agriculture (Sanders, 2013). In a small number of cases, organic agriculture has provided support under the RDP measures Axis 3 (improving life in rural areas and diversification of the rural economy). The total amount of resources devoted to organic agriculture from the European Fund for Development of Agriculture and Rural Development (EAFRD) for the period 2014-2020 amounts to 6.286 Billion Euros, or $6.4 \%$ of total EAFRD funds (€ 98,958) (IFOAM, 2016).

\section{Organic agriculture in the Republic of Serbia}

The Republic of Serbia has great, so far under-used, ecological, economic and social capacities for agricultural production. The natural characteristics of the soil, the availability of water resources, and climate provide broader framework for structuring of agriculture, that on such grounds, could be viable and sustainable. By activating these endogenous resources, it would increase competitiveness of agricultural production and 
rural development, while giving a positive contribution to the overall socio-economic development of the country (Roljević et al., 2012).

Although organic farming in Serbia has started to implemented since the beginning of the twentieth century, the development of this sector is very slow, and systematic collection and monitoring of data has started much later if we compared with other EU countries.

According to data FiBL/IFOAM area under organic production in Serbia in 2006 covered the are only 740 ha. Today it is under organic production 15,298 ha (certified and areas in conversion), accounting for $0.4 \%$ of agricultural land in Serbia (MAEP, 2015). Arable crops (55\%), orchards and vineyards (19\%) is dominated in the structure of crop production, while vegetable gardening practices only $1 \%$ of land in organic production system (Table 3 ).

Table 3. Areas under organic production in Serbia in 2015.

\begin{tabular}{|l|r|r|r|}
\hline Category & \multicolumn{1}{|c|}{$\begin{array}{c}\text { In the period of } \\
\text { conversion (ha) }\end{array}$} & $\begin{array}{c}\text { Certified areas } \\
\text { (ha) }\end{array}$ & \multicolumn{1}{c|}{$\begin{array}{c}\text { Total } \\
\text { (ha) }\end{array}$} \\
\hline Cereals & $2.069,05$ & $2.182,89$ & $4.251,94$ \\
\hline Industrial plants & $1.216,25$ & $1.458,14$ & $2.674,38$ \\
\hline Vegetable & 45,61 & 124,89 & 170,50 \\
\hline Fodder crops & 397,58 & 104,81 & $2.440,39$ \\
\hline Fruit & $1.291,13$ & $1.603,98$ & 70,94 \\
\hline $\begin{array}{l}\text { Medicinal and Aromatic } \\
\text { Plants }\end{array}$ & 2,67 & 68,27 & $1.894,93$ \\
\hline Rest & $1.844,55$ & 50,39 & $13.398,19$ \\
\hline Total arable land & $6.866,84$ & $6.531,36$ & $1.899,83$ \\
\hline Meadows and pastures & 802,63 & $1.097,19$ & $15.298,02$ \\
\hline Total & $7.669,47$ & $7.628,55$ & \\
\hline
\end{tabular}

Source: Direction for National referent laboratories, MAEP, 2015

In Serbia exsist about 2,000 individuals producers (cerficate holders) and 334 included cooperants (Simić, 2016). Individual producers have their own certificate and directly can make contract with one of the control organization for their production. On the other hand, production of subcontractors is subject of group certification, and producers make contracts with some of the companies, which is actually certificate holder, and who buys the whole production.

The biggest challenges of organic producers in Serbia are irregular and incomplete market supply with seed and planting material, especially in the required quantities; insufficient amounts of biological plant for protection products, organic fertilizers and compost. Market research has shown that in Serbia only consumes 2,500 - 3,000 t of ortanic ferilizer per annum (not including farm manure), but the needs are much bigger. These are primarily fertilizers that are imported from abroad, while the production of organic fertilizers, animal and / or plant origin deals only a handful of domestic manufacturers. As regards the scope and value of the organic market in Serbia, according to MAEP (2014) in 2013, the total quantity of exports amounted to 7,101 tons, which is 4.5 times 
more than in 2012 (1,562 tons), while the total value of exports in 2013 (101 million euros) was higher by 27 times compared to 2012 (3.74 million).

\section{The policy of support for organic agriculture in Serbia}

Legislation is the basis for sustainable development of organic production while providing effective functioning within the market. Application of standards in organic production guarantee fair competition and aims to protect the interests of consumers. The sector of organic agriculture in the Republic of Serbia is regulated by the Law on Organic Production ("Official Gazette of RS", No. 30/10 of 07th May 2010), which entered into force on 01 january 2011. This law and the accompanying regulations (Rulebook on control and certification in organic production and organic production methods and the ordinance on amending the rules on control and certification in organic production and organic production methods) regulate all matters relating to organic production methods, inspection and certification, processing, storage, transport, marketing and labeling of organic products. The control system for organic products in Serbia was established on the model of a control system that is prescribed EU regulations (Council Regulation (EC) No. 834/2007 and Commission Regulation (EZ) No. 889/2008). What is missing is a rulebook that would simplify lengthy and expensive procedures for the import of organic fertilizer, biological plant protection, sowing and planting material whose use is permitted in organic farming in the EU, and this makes it more difficult access to raw materials in organic production.

Agrarian policy in Serbia is under the Ministry of Agriculture and Environmental Protection and the Law on Agriculture and Rural Development ("Off. Gazette of RS", no. 41/2009 and 10/2013, Article 3) implementation of the policy is carried out through implementation of the Strategy for agriculture and rural development in the Republic of Serbia, the National Programme for agriculture, and the National Programme for Rural development. The implementation of agricultural policy is carried out through direct, market and structural incentives. Structural incentives include the rural development measures which relate to:

(1) Improving the competitiveness of agriculture and forestry. These incentives are implemented through investments in agricultural production and investment in agricultural product processing and marketing, regress of insurance premiums for crops, fruit perennial plantations, nursery and animals.

(2) The improvement of environmental programs, biodiversity conservation and diversification of the rural economy is realized through incentives for caring agroecologic measures, organic production, protection of plant and animal generic measures, compensation for missed income as a result of the implementation of good agricultural practices, animal welfare and other policies to protect and preserve the environment.

(3) Improving the quality of life in rural areas is being implemented through incentives for economic activity in terms of adding value to agricultural products, as well as the introduction and certification of food safety and quality, organic products and products 
with geographical indications, improving training in the field of rural development and investments for the improvement and development of rural infrastructure.

A total of 262 million euros is intended for the realization of the policy of incentives in agriculture and rural development in 2013 by Regulation (Sl. Gl. RS “, no. 20/13), whereby according to the Ministry of Agriculture and Environment, 234.8 million euro has been realized (MAEP, 2014, book 1). The most common form of subsidies are direct payments, to which $92 \%$ of total assets are devoted. The second most common form of incentives is support for rural development, for which about 10.5 million euros have been allocated in 2013 , i.e. $4 \%$ of total intended funds. As part of the funds intended for incentives for rural development, 1.7 million, or $16.6 \%$ is defined for the development of organic agriculture (Table 4).

On the other hand, the policy of implementing incentives in agriculture and rural development in 2016 has received 159 million euros in accordance with the Regulation (Sl. Gl. RS “, no. 8/16), which is 40\% less compared to 2013. Direct payments are still the most common, with a share of $86 \%$, but the share of rural development support increased to $9 \%$ in the total amount of funds. What is worrying is the fact that the funds intended for stimulating organic agriculture drastically reduced and in 2016, and amounted to only 747,000 euros, which is $5 \%$ of the funds intended for incentives for rural development.

Table 4. The amount of subsidies in agriculture and rural development in 2013 and 2016, converted into EUR

\begin{tabular}{|l|r|r|r|}
\hline & \multicolumn{1}{|c|}{$\mathbf{2 0 1 3}^{*}$} & $\mathbf{2 0 1 6}^{* *}$ & \multicolumn{1}{c|}{$\begin{array}{c}\text { Index } \\
\mathbf{2 0 1 6} / \mathbf{2 0 1 3}\end{array}$} \\
\hline Direct payments & $242,305,846.40$ & $137,844,597.90$ & -43.11 \\
\hline Rural development & $10,494,954.45$ & $14,941,510.97$ & 42.37 \\
\hline Organic farming & $1,745,200.70$ & $747,359.87$ & -57.18 \\
\hline Credit support & $4,363,001.75$ & $4,874,086.11$ & 11.71 \\
\hline Special support & $4,851,657.94$ & $1,889,926.89$ & -61.05 \\
\hline Total & $262,015,460.60$ & $159,550,121.90$ & -39.11 \\
\hline
\end{tabular}

Source: Regulation on the allocation of subsidies to agriculture and rural development in 2013. and 2016.

* Average exchange rate of the euro as of 31.12.2013 amounted to 114.6421 RSD

** Average exchange rate of the euro on the day of 31.05.2016 amounted to 123.1015 RSD

Incentives for organic farming introduced in 2004, provided that the types of support over the years has been changed as it has been changed amounts of incentives (Table no. 5). The adoption of the Rules on the use of incentives for organic production (“Offical gazette RS", No. 52/14) defines the types of incentives for organic production conditions, methods and forms required for entitlement to these incentives and the maximum amount of incentives per user and per type of individual measures. 
Incentives can be achieved at a premium for milk produced with organic production method, then in organic crop production, followed by the recovery of plant nutrition products are allowed for use in organic crop production, as well as in organic livestock production.

Table 5. Measures to support development of organic farming over the years

\begin{tabular}{|c|c|c|c|c|c|c|c|}
\hline Type of support & 2004-2005 & 2006 & 2007-2008 & 2009 & 2010-2011 & 2012 & 2013-2016 \\
\hline $\begin{array}{l}\text { Covering the } \\
\text { costs of control } \\
\text { and certification }\end{array}$ & घ & [ & & & & & घ \\
\hline $\begin{array}{ll}\text { Payments } & \text { per } \\
\text { hectare (ha) }\end{array}$ & & - & - & - & [ & & - \\
\hline $\begin{array}{l}\text { Payments per } \\
\text { head of cattle / } \\
\text { beehive }\end{array}$ & & घ & घ & - & घ & & घ \\
\hline $\begin{array}{l}\text { Payments for } \\
\text { the production } \\
\text { of reproductive } \\
\text { material }\end{array}$ & & & & $\mathbf{\square}$ & & & \\
\hline $\begin{array}{l}\text { Promotion, } \\
\text { establishing } \\
\text { demonstration } \\
\text { farms, education }\end{array}$ & & $\square$ & & & & & \\
\hline
\end{tabular}

Source: Simić, 2015

By starting the negotiation process for accession to the EU in the field of agriculture and rural development, there appears an imperative need to harmonize national policies for agriculture and rural development with the rules and principles of the Common Agricultural Policy. In order to help candidate countries to adapt the agricultural sector and rural areas to the premises of the Common Agricultural Policy, the EU provides support in the form of IPARD funds (Instrument for Pre-Accession Assistance in Rural Development).

Out of the total budget of IPARD II for the period of 2014-2020, intended for Serbia (EU contribution amouts 175.000 .000 euro, and national contribution 54.970.588 evra $)^{5}$, around $44 \%$ was planned for the measure "Investment in physical property of agricultural households" and around 35\% for the measure "Investment in physical property concerning processing and marketing agricultural products and fishery products". The measure "Diversification of agricultural households and business development" are planned to receive $10 \%$ of the total budget with the goal of stabilising income in rural areas. The planned investments for improving agri-eco-climate measures are $5 \%$ of the total budget. The agri-ecological measure most often given support to given support to is organic agriculture, both due to the overall gain it has for the environment and biodiversity protection, and for the increasing economic potentials of organic food.

5 Source: Ministry of Agriculture and Environment of the Republic of Serbia, Republic of Serbia IPARD program for the 2014-2020 Str 96, Belgrade, 2014

EP 2017 (64) 1 (323-337) 
IPARD measures will only support organic farmers involved in crop production (cultivation of cereals, oilseeds, vegetables, fruit or grapes and aromatic / medicinal plants), while the organic animal production and animal and plant genetic resources will be subject of support of the National Programme for Rural development. However, the impact of the current economic situation could reduce access to funds (Zefinescu et al., 2015).

IPARD funds will be available after the establishing of the institutional framework necessary for the implementation of IPARD. The preconditions that must be met for the aim accession IPARD funds are:

- it is essential to the formation of the governing body that will write the program, define measures that will implement and monitor the execution of the program, as well as

- establishment of IPARD Agency, which will be the intermediary between the accounts of EU funds and national accounts and transfer to the IPARD agency.

In 2016, by the Regulation on the allocation of subsidies to agriculture and rural development (Article 8) were the first time planned assets for participation in IPARD fund in the amount of 100 million dinars, and make $5.43 \%$ of the assets which are dedicated for rural development.

\section{Conclusion}

The sector of organic agriculture is growing rapidly, but it still only represents a small part of the global agriculture. The European Union is one of the world leaders in the sector of organic agriculture, both in the aspect of areas under organic production, scope of production and the market for organic products, as well as the aspect of developing systems of instititional support for this sector. The support for the development of organic agriculture in the EU is the Common Agricultural Policy, i.e. its second pillar. The assets meant for organic agriculture, from the European Agricultural Fund for Rural Development (EAFRD) for the period of 2014-2020 are 6.4\% of the total EAFRD fund. The development of organic agriculture in the Republic of Serbia has untill recently been quite slow, but it certainly possesses great natural potential for increase with adequate support and incentives.

Therefore, it is necessary greater consistency of relevant institutions in creating incentives and continuous payments. Beside that, it is alarming the fact that only in the last three years, assets allocated for organic production decreased a twice. On the other hand, if we take in mind the growth of demand for organic food and current market growth at the global level, primarily the European Union market, the organic sector in Serbia could be one of the factors of economic development of country. 


\section{Literature}

1. Direction for National referent laboratories, MAEP, 2015, http://www.dnrl. minpolj.gov.rs/o nama/organska.html

2. EUROSTAT http://ec.europa.eu/eurostat/statistics-explained/index.php/Organic farming_statistics

3. European Commission (2013): Overview of CAP Reform 2014-2020, DG Agriculture and Rural Development, Unit for Agricultural Policy Analysis and Perspectives

4. Lampkin N., Foster C., Padel S. (1999): The Policy and Regulatory Environment for Organic Farming in Europe: Country Reports, Organic Farming in Europe: Economics and Policy, no. Vol. 2. Universität Hohenheim, Stuttgart

5. Ministry of Agriculture and Environmental Protection (2014): Report on the state of agriculture in the Republic of Serbia in 2014, Book 1 and Book 2, http://www. mpzzs.gov.rs/korisna-dokumenta-i-linkovi/

6. Ministry of Agriculture and Environmental Protection (2014): Republika Srbija IPARD program for 2014-2020 http://ipard.co.rs/doc/srbija-ipard-2-program.pdf

7. Padel S., Lampkin N., Lockeretz, W. (2007): The development of governmental support for organic farming in Europe, Organic farming: An international history, 93-122.

8. Research Institute of Organic Agriculture (FiBL) and IFOAM - Organics International (2016): The World of Organic Agriculture, Statitics and Emerging Trends 2016, https://shop.fibl.org/fileadmin/documents/shop/1698-organicworld-2016.pdf

9. Roljević S. (2014): Productivity of alternative small grains in the organic farming system, doctoral dissertation Faculty of Agriculture, University of Belgrade, UDC 631.147:633.11(043.3)

10. Roljević S., Grujić B., Sarić R. (2012): Organic agriculture in terms of sustainable development and rural areas' development, Rural development policies from the EU enlargement perspective, European rural development network, Institute of agriculture and food economics - NRI, Institute of agricultural economics belgrade, Published by the Institute of Agricultural and Food Economics National Research Institute, Rural areas and development - vol. 9, Editors: Drago Cvijanović, Zbigniew Floriańczyk, ISBN: 978-83-7658-275-7, pp. 155-172

11. Sanders, J. (ed.) 2013: Evaluation of the EU legislation on organic farming, Braunschweig: Thünen Institute of Farm Economics

12. Sima, V., Gheorghe, I. G. (2015): Changing Consumption Patterns in Green Economy, Agricultural Management Strategies in a Changing Economy, 186. In Andrei J.V.(2016), Food Science, Production, and Engineering in Contemporary Economies, IGI Global USA

13. Simić I. (2015): Organska proizvodnja - neiskorišćen potencijal Republike 
Srbije, Strengthening of Civil Society, Norwegian Embassy http://eukonvent.org/ wp-content/uploads/2015/03/Neiskorisceni-potencijali-organske-proizvodnje Nakon-sednice FIN.pdf

14. Simić I. (2016): Organic Agriculture in Serbia At a Glance 2017, National Association Serbia Organica, http://www.serbiaorganica.info/wp-content/ uploads/2012/07/Organic-Agriculture-in-Serbia-At-a-glance-2017.pdf

15. Stolze, M., Sanders, J., Kasperczyk, N., Madsen G., (2016): CAP 2014-2020: Organic farming and the prospects for stimulating public goods. IFOAM EU, Brussels

16. Regulation on the allocation of subsidies to agriculture and rural development in 2013, „Official Gazette RS”, No. 20/13

17. Regulation on the allocation of subsidies to agriculture and rural development in 2016, „Official Gazette RS ”, No. 8/16

18. Westhoek, H., Van Zeijts, H., Witmer, M., Van den Berg, M., Overmars, K., Van der Esch, S., Van der Bilt, W. (2014): Greening the CAP. An analysis of the effects of the European Commission's proposals for the Common Agricultural Policy 2014-2020, Netherlands Environmental Assessment Agency

19. Willer Helga, Schaack Diana, Lernoud Julia, Meredith Stephen (2015): Growth trends in European organic food and farming, pp. 20-58, in publication: Stephen Meredith and Helga Willer eds (2015): Organic in Europe prospects and developments 2016, IFOAM EU Group, FiBL

20. Law on Agriculture and Rural Development „Official Gazette RS”, No. 41/2009 and $10 / 2013$

21. Zefinescu, C., Ibrahim, M. A., Popovic, V., Mieila, M. (2015): Measuring the economic performance in decision making process in the contemporary economies. Procedia Economics and Finance, vol. 22, pp. 380-38 


\title{
MERE PODRŠKE RAZVOJU ORGANSKE POLJOPRIVREDE
} U EU I SRBIJI ${ }^{6}$

\section{Svetlana Roljević Nikolić7, Predrag Vukovićc ${ }^{8}$, Biljana Grujićc}

\begin{abstract}
Apstrakt
Cilj rada je analiza stanja sektora organske poljoprivrede, kao i sistema podrške koji se ovoj ekološkoj proizvodnji pruža u Evropskoj uniji i Srbiji. Organska poljoprivreda pokazuje dinamičan proces rasta i razvoja, naročito u ekonomski razvijenim državama. $U$ proteklih deset godina površine pod organskom proizvodnjom u EU uvećane su za 70\%, broj sertifikovanih proizvođača veći je za 60\%, dok je ukupna vrednost tržišta udvostručena. Sa druge strane, rast i razvoj organske poljoprivrede u Srbiji je veoma spor. Trenutno, površine pod organskom proizvodnjom čine svega 0,4\% ukupno korišćenog poljoprivrednog zemljišta, dok je za ovaj način proizvodnje hrane sertifikovano 0,3\% od ukupnog broja poljoprivrednih gazdinstava.

Intezivan rast organske poljoprivrede u EU omogućen je stabilnom podrškom kako u pogledu mera, tako $i$ finansijskih sredstava, dok se u Srbiji iz godine u godinu menjaju ne samo iznosi samih podsticaja, već i tipovi podrške. Na osnovu toga, može se zaključiti da je stabilna podrška države ključna za podsticanje rasta i unapređenje sektora organske poljoprivredne proizvodnje.
\end{abstract}

Ključne reči: organska poljoprivreda, poljoprivredna politika, mere podrške.

6 Rad predstavlja deo istraživanja na projektu 46006: “Održiva poljoprivreda i ruralni razvoj u funkciji ostvarivanja strateških ciljeva Republike Srbije u okviru dunavskog regiona”, kao i projekta 179028: „Ruralno tržište rada i ruralna ekonomija Srbije - diverzifikacija dohotka i smanjenje ruralnog siromaštva“ finansiranih od strane Ministarstva prosvete, nauke i tehnološkog razvoja Republike Srbije

7 Dr Svetlana Roljević Nikolić, naučni saradnik, Institut za ekonomiku poljoprivrede, Beograd, Volgina Ulica br. 15, 11060 Beograd, Srbija, E-mail: svetlana_r@iep.bg.ac.rs , Telefon: +381 11 6972858 ;

8 Dr Predrag Vuković, istraživač saradnik, Institut za ekonomiku poljoprivrede, Beograd, Volgina Ulica br. 15, 11060 Beograd, Srbija, E-mail: predrag_v@,iep.bg.ac.rs, Telefon: +381 116972858

9 MA Biljana Grujić, istraživač saradnik, Institut za ekonomiku poljoprivrede, Beograd, Volgina 15, 11060 Beograd, Srbija, email: biljana_g@iep.bg.ac.rs

EP 2017 (64) 1 (323-337) 
ECONOMICS OF

AGRICULTURE

\section{CONTENT}

1. Željko Anđelković, Aleksandra Dragin, Sanja Božić, Kristina Košić

EMOTIONAL EXHAUSTION AND JOB SATISFACTION OF TOUR GUIDES IN RURAL AREAS . . . . . . . . . . . . . . 11

2. Sanja Đukić, Danica Glavaš-Trbić, Nikola Banjac

MANAGEMENT PROBLEMS OF RURAL DEVELOPMENT IN FRUŠKA GORA . . . . . . . . . . . . . . . . . . . . 27

3. Ivana Ilić, Bojan Krstić, Sonja Jovanović

ENVIRONMENTAL PERFORMANCES OF AGRICULTURE IN THE EUROPEAN UNION COUNTRIES . . . . . . . . . . . . . 41

4. Nataša Kljajić, Jonel Subić, Zorica Sredojević

PROFITABILITY OF RASPBERRY PRODUCTION

ON HOLDINGS IN THE TERRITORY OF ARILJE. . . . . . . . . . . 57

5. Aleksandar Maksimović, Zoran Grgić, Ferhat Ćejvanović

MULTI-ATTRIBUTE ANALYSIS OF ORCHARD ACCORDING

TO THE INTEGRATED PRODUCTION CONCEPT . . . . . . . . . . 69

6. Ozrislava Milinković, Branislav Jakić, Slobodan Vuksanović,

Dragana Macura, Milica Šelmić

MULTI- CRITERIA DECISION BASED APPROACH

TO SELECTING THE TYPE OF INDUSTRIAL HALLS

USED IN FOOD INDUSTRY $\ldots \ldots \ldots \ldots$. . . . . . . . . . 81

7. Gordana Nikić, Ljubiša Stamatović, Azra Sućeska

EMOTIONAL COMPETENCIES AND PERSONALITY

TRAITS OF MANAGERS IN MODERN AGROBUSINESS. . . . . . . .97

8. Vladimir Obradović, Nemanja Karapavlović

FINANCIAL REPORTING OF COMPREHENSIVE INCOME

IN THE FOOD AND BEVERAGE SECTOR

IN THE REPUBLIC OF SERBIA . . . . . . . . . . . . . . 113 
9. Aleksandar Ostojić, Nebojša Savić, Željko Vaško

CONSUMER ATTITUDES

ON BUYING FISH IN BANJA LUKA . . . . . . . . . . . . . . . 129

10. Radivoj Prodanović, Boris Kuzman, David Jovović, Lazar Ozegović

MARKET AND TRADE OF ORGANIC FRUITS IN SERBIA $\ldots . . .141$

11. Predrag Vukadinović, Aleksandar Damnjanović, Ljiljana Dimitrijević

ANALYSIS OF THE SALES AND INCOMES BETWEEN

DIFFERENT CATEGORIES OF AGRICULTURAL PRODUCTS . . . 157

12. Jugoslav Aničić, Svetlana Vukotić, Goran Maksimović

THE POSSIBILITIES AND LIMITATIONS

OF ENTREPRENEURSHIP DEVELOPMENT

IN AGRICULTURE IN SERBIA . . . . . . . . . . . . . . 171

13. Željko Bjelajac, Marijana Dukić - Mijatović, Joko Dragojlović

FOOD SAFETY AS ONE OF THE MAIN SAFETY $P$

REOCCUPATIONS OF A MODERN MAN . . . . . . . . . . . . . 191

14. Milan Bradić, Ljiljana Kosar, Lukrecija Djeri, Svetlana Vukosav, Vuk Garača

ECO-LABELLING OF ACCOMMODATION FACILITIES

AND ITS PERCEPTION BY RURAL TOURISTS:

CASE STUDY OF VOJVODINA . . . . . . . . . . . . . . 205

15. Vaso Jegdić, Iva Škrbić, Srđan Milošević

MODELS OF ENTREPRENURSHIP DEVELOPMENT

IN RURAL TOURISM DESTINATIONS IN VOJVODINA . . . . . . . 221

16. Duško Kuzović

MUSEUM OF VERNACULAR ARCHITECTURE OF WESTERN SERBIA

- Representative curtilages of the area surrounding middle

course of the river Drina and Podgorina . . . . . . . . . . . 239

17. Branko Mihailović, Zoran Simonović, Nikola Ćurčić

AGRICULTURAL RESOURCES AND DEVELOPMENT

PRIORITIES OF THE MUNICIPALITY OF STARA PAZOVA. . . . . 259

18. Radmilo Nikolić, Aleksandra Fedajev, Vidoje Stefanović, Silvana Ilić

THE AGRICULTURE SECTOR IN WESTERN BALKANS

- SOME CHARACTERISTICS OF DEVELOPMENT. . . . . . . . . . 275

19. Vladimir Njegomir, Rajko Tepavac, Nenad Ivanišević

ALTERNATIVE SOURCES OF FINANCING

ENTREPRENEURIAL UNDERTAKINGS IN AGRICULTURE . . . 295

Economics of Agriculture, Year 64, No. 1 (1-404) 2017, Belgrade 
20. Daniela Nuševa, Kristina Mijić, Dejan Jakšić

THE PERFORMANCES OF COFFEE PROCESSORS

AND COFFEE MARKET IN THE REPUBLIC OF SERBIA . . . . . . 307

21. Svetlana Roljević Nikolić, Predrag Vuković, Biljana Grujić

MEASURES TO SUPPORT THE DEVELOPMENT OF ORGANIC

FARMING IN THE EU AND SERBIA . . . . . . . . . . . . 323

22. ŽeljkoVojinović, Vera Zelenović, DragoCvijanović

PROGRAM OF STATE SUPPORT

TO AGRICULTURAL CREDITING. . . . . . . . . . . . . . . . 339

23. Nikola Vuksanović, Dragan Tešanović, Bojana Kalenjuk,

Milijanko Portić, Marija Knežević

SOCIO-DEMOGRAPHIC CHARACTERISTICS

AS DETERMINANTS OF DIFFERENCES

IN PERCEPTION OF LOCAL GASTRONOMY . . . . . . . . . . . . 359 